\title{
The C242T polymorphism of the gene encoding cytochrome b-245 alpha is not associated with paediatric ischaemic stroke: family-based and case-control study
}

\section{Polimorfizm C242T genu koduiqcego cytochrom b-245 alfa nie jest zwiqzany z udarem niedokrwiennym mózgu u dzieci: analiza wewnq̨trzrodzinna i badanie kliniczno-kontrolne}

\author{
Paweł Niemiec', Iwona Żak', Ewa Emich-Widera², Anna Balcerzyk', Ilona Kopyta², Tomasz Nowak', Jerzy Wendorff ${ }^{3}$ \\ Katarzyna Pałatyńska ${ }^{3}$, Marek Kaciński ${ }^{4}$, Karolina Pienczk-Ręcławowizz ${ }^{5}$ Ewa Pilarska ${ }^{5}$ \\ 'Department of Biochemistry and Medical Genetics, School of Health Care, Medical University of Silesia, Katowice, Poland \\ ${ }^{2}$ Department of Neuropaediatrics, School of Medicine in Katowice, Medical University of Silesia, Katowice, Poland \\ ${ }^{3}$ Department of Neurology, Polish Mother's Memorial Hospital - Research Institute, tódź, Poland \\ ${ }^{4}$ Department of Paediatric and Adolescent Neurology, Medical College, Jagiellonian University, Kraków, Poland \\ ${ }^{5}$ Department of Developmental Neurology, School of Medicine, Medical University of Gdansk, Gdańsk, Poland
}

Neurologia i Neurochirurgia Polska 2010; 44, 5: 453-458

\begin{abstract}
Background and purpose: Reactive oxygen species play an important role in the physiology and pathology of cerebral arteries, including ischaemic stroke. The cytochrome b-245 alpha gene $(C Y B A)$ encodes cytochrome b-245 alpha light chain (p22phox peptide), a critical element of $\mathrm{NAD}(\mathrm{P}) \mathrm{H}$ oxidases, the most important source of superoxide anion in the cerebral arteries. To search for genetic factors associated with paediatric ischaemic stroke, the possible association between CYBA gene C242T polymorphism and the disease was evaluated.

Material and methods: The study group consisted of 238 individuals: children with ischaemic stroke $(n=70)$, their biological parents $(n=118)$ and children without any symptoms of stroke $(n=50)$. The $\mathrm{C} 242 \mathrm{~T}$ polymorphism was genotyped using polymerase chain reaction - restriction fragment length methodology. To evaluate the possible association between polymorphism and stroke, the transmission disequilibrium test and the case-control method were applied. Results: The C242 allele was transmitted more frequently than $242 \mathrm{~T}$ ( $62.2 \%$ vs. $37.8 \%)$ but observed frequencies did
\end{abstract}

\section{Streszczenie}

Wstęp i cel pracy: Reaktywne formy tlenu pełnią istotną funkcję zarówno w fizjologii, jak i patologii tętnic mózgowych, także w patogenezie udaru niedokrwiennego mózgu. Gen cytochromu b-245 alfa (gen CYBA) koduje lekki łańcuch cytochromu b-245 (białko p22phox), kluczowy składnik oksydaz $\mathrm{NAD}(\mathrm{P}) \mathrm{H}$, najważniejszego źródła anionorodnika ponadtlenkowego w obrębie tętnic mózgowych. W niniejszej pracy, poszukując genetycznych czynników ryzyka predysponujących do udaru mózgu u dzieci, oceniano możliwe związki pomiędzy polimorfizmem C242T genu CYBA i chorobą.

Materiał i metody: W badaniu wzięło udział 238 osób: 70 dzieci z udarem niedokrwiennym mózgu, 118 ich biologicznych rodziców oraz 50 dzieci bez żadnych objawów udaru. Polimorfizm C242T genu CYBA genotypowano metodą polimorfizmu długości fragmentów restrykcyjnych $\mathrm{w}$ reakcji łańcuchowej polimerazy. Do oceny możliwych związków pomiędzy polimorfizmem i udarem zastosowano dwie niezależne metody: wewnątrzrodzinny test transmisji i badanie kliniczno-kontrolne. Wyniki: Allel C242 był częściej przekazywany chorym dzieciom przez heterozygotycznych rodziców niż allel $242 \mathrm{~T}$

Correspondence address: Pawel Niemiec, Department of Biochemistry and Medical Genetics, Medical University of Silesia, Medykow 18, 40-752 Katowice, Poland, e-mail: pniemiec@sum.edu.pl

Received: 30.06.2010; accepted: 15.09.2010 
Paweł Niemiec, Iwona Żak, Ewa Emich-Widera, Anna Balcerzyk, Ilona Kopyta, Tomasz Nowak, Jerzy Wendorff, Katarzyna Pałatyńska, Marek Kaciński, Karolina Pienczk-Ręctawowicz, Ewa Pilarska

not differ significantly from expected $(p=0.10)$. There were also no significant differences in allele and genotype distribution between patients and control subjects (patients: $\mathrm{CC}-$ $50.0 \%, \mathrm{CT}-38.6 \%$, TT $-11.4 \%$ vs. controls: $\mathrm{CC}-52.0 \%$, $\mathrm{CT}-36.0 \%$, TT $-12.0 \%)$.

Conclusions: The study did not show that the C242T polymorphism of the CYBA gene is a risk factor of ischaemic stroke in children.

Key words: ischaemic stroke, paediatric stroke, polymorphism, $C Y B A$ gene, free radicals, $\mathrm{NAD}(\mathrm{P}) \mathrm{H}$ oxidases.

\section{Introduction}

Paediatric ischaemic stroke has a multifactorial and certainly multigenic inheritance pattern [1]. The main causes of paediatric ischaemic stroke are cerebral arteriopathies, cardiac diseases, traumas, infections, metabolic and mitochondrial diseases, as well as other various conditions. It is also generally accepted that ischaemic stroke in children often has a thrombotic background, as a result of endothelial dysfunction and various disorders of blood coagulation cascade elements, manifested by hypercoagulability $[1,2]$. Although atherosclerosis is the main cause of cerebrovascular insufficiency of adult ischaemic stroke patients [3], it seems to be rather marginal in paediatric stroke and limited only to rare monogenic disorders such as familial hypercholesterolaemia. In fact, some classical risk factors of adult stroke such as hypercholesterolaemia or hypertension are relatively common in paediatric patients $[4,5]$ and most children have several potential risk factors rather than one single cause, although up to $50 \%$ of all cases are cryptogenic [2].

There is growing evidence for the role of reactive oxygen species (ROS) in the physiology as well as pathology of cerebral arteries, including ischaemic stroke. ROS serve as important cell-signalling molecules in the cerebral circulation and play an important role in cerebrovascular tone regulation $[6,7]$. In the pathological state reactive oxygen species may disrupt redox balance into the vessel wall, leading to vasoconstriction, endothelial dysfunction, and atherosclerotic plaque formation [8-10]. Furthermore, ROS are involved in the initiation of the blood coagulation cascade [11] and platelet activation [12]. Focal brain ischaemia occurring after stroke has also been shown to be associated with ROS-mediated reactions potentially leading to neuronal death [13].
(62,2\% w porównaniu z 37,8\%), jednak obserwowane częstości nie odbiegały znamiennie od oczekiwanych $(p=0,10)$. Nie wykazano także znaczących różnic w rozkładzie alleli i genotypów pomiędzy pacjentami i dziećmi z grupy kontrolnej (pacjenci: CC - 50,0\%, CT - 38,6\%, TT - 11,4\%; grupa kontrolna: CC $-52,0 \%, \mathrm{CT}-36,0 \%, \mathrm{TT}-12,0 \%$ ).

Wnioski: Wyniki badań nie wykazały, aby polimorfizm C242T genu CYBA był czynnikiem ryzyka udaru niedokrwiennego u dzieci.

Słowa kluczowe: udar niedokrwienny, udar dziecięcy, polimorfizm, gen $C Y B A$, wolne rodniki, oksydazy NAD $(\mathrm{P}) \mathrm{H}$.

The superoxide anion is the major vascular ROS, in both cerebral and non-cerebral arteries, and the vascular NAD $(\mathrm{P}) \mathrm{H}$ oxidases are the main source of superoxide in the vasculature [6-9]. $\mathrm{NAD}(\mathrm{P}) \mathrm{H}$ oxidases are a group of multisubunit enzymes catalyzing the production of superoxide from oxygen [6-9]. They are present in many types of cells including endothelial and vascular smooth muscle cells of cerebral arteries $[8-10,14]$ and are located in the plasma membranes, consisting of at least six components: membrane bound catalytic NOX subunit (NOX-NADPH oxidase) and p22phox (phox-phagocyte oxidase), as well as cytosolic p47phox, p67phox, p40phox and small G protein Rac.

p22phox is a common element of mammalian NAD $(\mathrm{P}) \mathrm{H}$ oxidases, serving as a link between NOX peptide and cytosolic phox subunits [8-10]. p22phox is encoded by the cytochrome b-245 alpha (CYBA) gene (16q24) [15]. The transition of $\mathrm{C}$ to $\mathrm{T}$ in the 242 nucleotide position of the $C Y B A$ gene is associated with conversion of histidine to tyrosine in a 72 amino acid residue, located in the cytosolic loop of $\mathrm{p} 22$ phox pepti$\mathrm{de}$, and influences superoxide production.

To date, there are no studies concerning the $C Y B A$ C242T polymorphism in paediatric ischaemic stroke patients. Therefore in the present work we investigated whether the $C Y B A$ polymorphism is associated with the ischaemic stroke risk in children, using two different methods: a family-based association test and the casecontrol model.

\section{Material and methods}

\section{Subjects}

The study group consisted of 238 individuals, including 70 children with ischaemic stroke, their biolo- 
gical parents $(n=118)$, and 50 children without any symptoms of ischaemic stroke. There were 41 males and 29 females in the patient group, and their age at the acute phase of stroke ranged from 6 months to 18 years (mean $8.4 \pm 5.3$ ). Participants were recruited from the Department of Neuropaediatrics at the Medical University of Silesia in Katowice, the Department of Neurology at the Polish Mother's Memorial Hospital in Lodz, the Department of Developmental Neurology at the Medical University of Gdansk and the Department of Paediatric and Adolescent Neurology, Medical College at the Jagiellonian University. Neurological examinations and neuroimaging were performed at least twice (at the acute phase and during follow-up). The stroke subtypes were evaluated using the Oxfordshire classification [16].

The control group of 50 children was age- and sexmatched (26 males, 24 females, age ranging from 1 to 18 years, mean $9.0 \pm 6.1$ ). These children had no signs of ischaemic stroke or other vascular diseases.

The study protocol was approved by the Ethics Committee of the Medical University of Silesia in Katowice and written consent was provided by the parents of the patients.

\section{Genetic analysis}

Genomic DNA was extracted from peripheral leucocytes. The $\mathrm{C} 242 \mathrm{~T}$ polymorphism of the CYBA gene was genotyped using PCR-RFLP (polymerase chain reaction - restriction fragment length polymorphism), with RsaI as a restrictase. The method was previously described in detail, including reagents used [17].

\section{Statistical analysis}

The statistical methods were also previously described in detail [5]. Briefly, the role of C242T polymorphism in paediatric ischaemic stroke has been tested by two independent methods: a family-based association test - the transmission/disequilibrium test (TDT); and the classical case-control model. Transmission of a particular allele from heterozygous parents to an offspring is expected to be approximately $50 \%$, when there is no association of the allele and the disease. If the allele is associated with an increased risk of the disease, excess transmission to the offspring is expected. The observed frequencies of transmitted alleles were compared with the expected frequencies by means of the $\chi^{2}$ test. Similarly, the $\chi^{2}$ test was used in the case-control model. Odds ratios (OR) as well as their $95 \%$ confidence intervals (CI) for $C Y B A$ genotypes were computed using univariate regression model analysis. Statistica 7.1 software (STATSOFT, Tulsa, OK) was used in all analyses.

\section{Results}

\section{Clinical analysis}

Clinical characteristics of stroke children are shown in Table 1. The main symptoms of the onset of stroke were: central facial palsy, hemiparesis, consciousness disturbances and aphasia. The most frequent were incidents of partial anterior circulation infarct. The most frequent post-stroke symptoms diagnosed during follow-up examination were: hemiparesis, epilepsy and

Table 1. Clinical characteristics of children with ischaemic stroke

\begin{tabular}{|lc|}
\hline Demographics & Stroke group \\
\hline$n$ & 70 \\
\hline Sex (male/female) & $41 / 29$ \\
\hline Age at the time of stroke, years (mean \pm SD) & $8.48 \pm 5.44$ \\
\hline Symptoms and signs at the time of stroke*, $\boldsymbol{n}$ (\%) \\
\hline Hemiplegia & $9(14.8)$ \\
\hline Hemiparesis & $45(73.8)$ \\
\hline Central facial palsy & $50(83.6)$ \\
\hline Consciousness disturbances & $38(62.3)$ \\
\hline Vertigo/dizziness & $31(50.8)$ \\
\hline Aphasia & $35(57.4)$ \\
\hline Other stroke symptoms & $29(47.5)$ \\
\hline Type of stroke*, $\boldsymbol{n}$ (\%) & $13(21.3)$ \\
\hline Total anterior circulation infarct & $24(39.3)$ \\
\hline Partial anterior circulation infarct & $15(24.6)$ \\
\hline Lacunar infarct & $9(14.8)$ \\
\hline Posterior circulation infarct & $14(23.0)$ \\
\hline Symptoms and signs at the time of follow-up examination* \\
$\boldsymbol{n}$ (\%)
\end{tabular}

* Data available from 61 patients

$S D-$ standard deviation 
Paweł Niemiec, Iwona Zak, Ewa Emich-Widera, Anna Balcerzyk, Ilona Kopyła, Tomasz Nowak, Jerzy Wendorff, Katarzyna Pałatyńska, Marek Kaciński, Karolina Pienczk-Ręctawowicz, Ewa Pilarska

other movement disorders and decrease of intellectual functioning. As previously reported, more than $67 \%$ of the stroke patients had lipometabolic disorders [5].

\section{Genotype analysis}

The genotype frequencies were consistent with the Hardy-Weinberg equilibrium in the patients $(p=0.66$ ) and in the control group $(p=0.47)$. In the transmission disequilibrium test, 50 full families were finally qualified, yielding 33 informative trios, defined as families with at least one heterozygous parent. Only in such informative families was it possible to deduce which allele had been transmitted from a parent to the child. The number of transmitted alleles was 28 for the $\mathrm{C} 242$ allele $(62.2 \%)$ and 17 for the $242 \mathrm{~T}$ allele $(37.8 \%)$. The $\mathrm{C} 242$ allele was transmitted more frequently but the observed frequencies of both alleles did not differ significantly from expected $\left(\chi^{2}=2.68, p=0.10\right.$ for both alleles) (Table 2).

Data from genotyping of the CYBA gene C242T polymorphism are shown in Table 3 . We did not observe any statistical differences in the distribution of genotypes and alleles between stroke children and controls (Table 3). There were no differences in the distribution of genotypes and alleles of the C242T CYBA polymorphism between respective stroke classes as well as symptoms of the onset of stroke and post-stroke symptoms diagnosed during follow-up examination (data not shown).

\section{Discussion}

The substitution in the 242 nucleotide position of the CYBA gene results in differences in superoxide synthesis by $\mathrm{NAD}(\mathrm{P}) \mathrm{H}$ oxidases. Although there are conflicting results from functional studies on the $\mathrm{C} 242 \mathrm{~T}$ polymorphism [18-21], enhanced superoxide anion production and increased low density lipoprotein oxidation are more often attributed to the $242 \mathrm{~T}$ allele [19-21]. There are no references in the literature to $C Y B A$ C242T polymorphism in paediatric ischaemic stroke patients. Previous studies in stroke patients were not numerous and were conducted in adults, with non-comparable results due to ethnic differences. Most of the studies concerned the Japanese population, where the $242 \mathrm{~T}$ allele was associated with ischaemic stroke in one report [22]. Another two Japanese reports did not associate the C242T polymorphism with stroke $[19,23]$. Only one study was conducted in a Caucasian population of patients with ischaemic stroke or transient ischaemic attack under the age of 50 years. The authors found that homozygosity of the $242 \mathrm{~T}$ variant was associated with an enhanced risk for cerebral ischaemia [24].

The present study did not reveal statistically significant differences in the frequency of transmission between C242 and $242 \mathrm{~T}$ alleles in the TDT analysis $(p=0.10)$. There was, however, a tendency to markedly preferential transmission of the $\mathrm{C} 242$ allele from heterozygous parents to affected children (62.2\% for

Table 2. Transmission disequilibrium test for CYBA alleles in children with ischaemic stroke

\begin{tabular}{|lccccc|}
\hline Allele & Transmitted $(\boldsymbol{n})$ & Not transmitted $(\boldsymbol{n})$ & Predicted $(\boldsymbol{n})$ & $\boldsymbol{\chi}^{\mathbf{2}}$ & p-value \\
\hline $\mathrm{C} 242$ & 28 & 17 & 22.5 & 2.69 & 0.10 \\
\hline $242 \mathrm{~T}$ & 17 & 28 & 22.5 & 2.69 & 0.10 \\
\hline
\end{tabular}

Table 3. Distribution of genotypes and alleles of the C242T polymorphism of the CYBA gene

\begin{tabular}{|lcccc|}
\hline Genotype/ allele & Children with stroke & Control group & \multicolumn{2}{c|}{ Stroke/controls* } \\
\cline { 2 - 5 } & $\boldsymbol{n}(\%)$ & $\boldsymbol{n}(\%)$ & $\boldsymbol{\chi}^{\mathbf{2}}$ & $\mathbf{p}$-value \\
\hline CC & $35(50.0)$ & $26(52.0)$ & 0.05 & 0.83 \\
\hline CT & $27(38.6)$ & $18(36.0)$ & - & - \\
\hline TT & $8(11.4)$ & $6(12.0)$ & 0.01 & 0.92 \\
\hline C242 & $97(69.3)$ & $70(70.0)$ & 0.01 & 0.91 \\
\hline 242 T & $43(30.7)$ & $30(30.0)$ & 0.01 & 0.91 \\
\hline
\end{tabular}

*Comparison of stroke children with the controls 
C242 allele vs. $37.8 \%$ for $242 \mathrm{~T}$ allele). The case-control model also did not reveal any statistically significant differences in the distribution of alleles and genotypes between patients and controls. The cause of the casecontrol analysis results may be the specificity of $C Y B A$ polymorphism, the phenotype of which is probably manifested during exposure to $\mathrm{NAD}(\mathrm{P}) \mathrm{H}$ oxidase activators, such as thrombin, hyperglycaemia, hypercholesterolaemia or cigarette smoking. We previously showed that the $242 \mathrm{~T}$ allele interacts synergistically with some of these agents, significantly increasing the risk of coronary artery disease [17], and the observed effects were not related to absolute values of allele/genotype frequencies (no differences between groups in the case-control model) but resulted from interactions between elevated superoxide anion production by the $242 \mathrm{~T}$ allele, hypercholesterolaemia and cigarette smoking [17].

Although the role of ROS in the physiology and pathology of coronary arteries is rather well understood, their effects on the cerebral circulation are complex and have not been fully defined. Superoxide and hydrogen peroxide, a product of superoxide anion dismutation, are involved in many pathological actions including: endothelial damage; vasoconstriction; stimulation of expression of adhesion molecules, chemoattractants and matrix metalloproteinases (MMPs); hypertrophy and proliferation of vascular smooth muscle cells; and low density lipoprotein oxidation [8-10]. Additionally, the oxidase-derived ROS induce the expression of tissue factor, the main initiator of the blood coagulation cascade [11], and promote platelet aggregation [12], which may be a potential link between oxidative stress and ischaemic stroke, including in children.

On the other hand, there is growing evidence suggesting that $\mathrm{NAD}(\mathrm{P}) \mathrm{H}$ oxidase-derived ROS may serve as physiological regulators of cerebral arteries. The $\mathrm{NAD}(\mathrm{P}) \mathrm{H}$ oxidases are expressed constitutively in the cerebral vasculature and the enzyme-dependent $\mathrm{O}_{2}{ }^{-}$ production is up to 90 -fold greater in intracranial cerebral arteries (i.e. basilar and middle cerebral) versus noncerebral arteries (i.e. aorta, common carotid) at physiological level [14]. Both superoxide and hydrogen peroxide regulate cerebrovascular tone and its effect is probably concentration-dependent, with relaxation of vascular smooth muscle cells occurring at low concentrations and contraction of arteries at higher concentrations $[6,7,14]$.

We observed elevated, but not statistically significantly, transmission of the $\mathrm{C} 242$ allele, which is associated with decreased $\mathrm{O}_{2}{ }^{-}$production. The classical risk factors of atherosclerosis seem to be a rather marginal cause of paediatric stroke, as mentioned above. So we may assume that the chronic and maintaining vasoconstriction associated with $242 \mathrm{~T}$ allele-related elevated $\mathrm{O}_{2}{ }^{-}$ production, which increases the effect of classical risk factors, is a rather infrequent phenomenon in children. It is more probable that the vasoconstriction of infantile cerebral arteries will be related to decreased levels of vasodilatative reactive oxygen species, partly associated with the phenotypic manifestation of $\mathrm{C} 242$ allele presence.

Although our understanding of the role of ROS in paediatric ischaemic stroke is fragmentary and extrapolated from the studies on tissues, animal models and adults, it seems very likely that local changes in concentration of free radicals can increase the inter-individual predisposition to early children's ischaemic stroke. However, to date, there are no simple methods to verify these speculations. In conclusion, the CYBA gene C242T polymorphism seems not to be a good predictor of paediatric ischaemic stroke; the results of the present work, however, should not discourage researchers to study the role of reactive oxygen species and $\mathrm{NAD}(\mathrm{P}) \mathrm{H}$ oxidases in the context of paediatric ischaemic stroke.

The main limitation of this study is the number of included patients. It should be pointed out, however, that the participants were recruited through cooperation with four major neurology centres in Poland. The low frequency of paediatric stroke (2-4/100 000/year) and a methodology requiring whole families were the main obstacles to enlargement of the patient group.

\section{Conclusions}

The study did not show that the $\mathrm{C} 242 \mathrm{~T}$ polymorphism of the $C Y B A$ gene is a risk factor of ischaemic stroke in children.

\section{Acknowledgements}

This study was supported within the project KNW2-020/08 of the Medical University of Silesia. Preliminary data were presented at the XLIV Annual Meeting of the Polish Biochemical Society in Lodz, 2009.

\section{Disclosure}

The authors report no conflict of interest. 


\section{References}

1. Pavlakis S.G., Kingsley P.B., Bialer M.G. Stroke in children: genetic and metabolic issues $J$ Child Neurol 2000; 15: 308-315.

2. Kirkham F., Sébire G., Steinlin M., et al. Arterial ischaemic stroke in children. Review of the literature and strategies for future stroke studies. Thromb Haemost 2004; 92: 697-706.

3. Jędrzejewska J., Członkowska A., Kobayashi A. Pomostowanie aortalno-wieńcowe u osób z objawowym lub bezobjawowym zwężeniem tętnicy szyjnej wewnętrznej [Article in Polish]. Neurol Neurochir Pol 2009; 43: 263-271.

4. Kopyta I., Marszal E. Czynniki ryzyka udaru mózgu u dzieci [Article in Polish]. Udar Mozgu 2004; 6: 47-55.

5. Balcerzyk A., Zak I., Niemiec P., et al. APOE gene e polymorphism does not determine predisposition to ischemic stroke in children. Pediatr Neurol 2010; 43: 25-28.

6. Miller A.A., Drummond G.R, Sobey C.G. Novel isoforms of NADPH-oxidase in cerebral vascular control. Pharmacol Ther 2006; 111: 928-948.

7. Miller A.A., Drummond G.R., Sobey C.G. Reactive oxygen species in the cerebral circulation: are they all bad? Antioxid Redox Signal 2006; 8: 1113-1120.

8. Niemiec P., Zak I. Naczyniowe oksydazy NAD(P)H znaczenie w patogenezie miażdzycy [Article in Polish]. Postepy Biochem 2005; 51: 1-11.

9. Lassegue B., Clempus R.E. Vascular NAD(P)H oxidases: specific features, expression, and regulation. Am J Physiol Regul Integr Comp Physiol 2003; 285: R277-R297.

10. Guzik T.J., West N.E., Black E., et al. Vascular superoxide production by $\mathrm{NAD}(\mathrm{P}) \mathrm{H}$ oxidase: association with endothelial dysfunction and clinical risk factors. Circ Res 2000; 86: E85-E90.

11. Herkert O., Diebold I., Brandes R.P., et al. NADPH oxidase mediates tissue factor-dependent surface procoagulant activity by thrombin in human vascular smooth muscle cells. Circulation 2002; 105: 2030-2036

12. Krötz F., Sohn H.Y., Gloe T. NAD(P)H oxidase-dependent platelet superoxide anion release increases platelet recruitment. Blood 2002; 100: 917-924.

13. Alexandrova M., Bochev P., Markova V., et al. Dynamics of free radical processes in acute ischemic stroke: influence on neurological status and outcome. J Clin Neurosci 2004; 11: 501-506.

14. Miller A.A., Drummond G.R., Schmidt H.H., et al. NADPH oxidase activity and function are profoundly greater in cerebral versus systemic arteries. Circ Res 2005; 97: 1055-1062.

15. Dinauer M.C., Pierce E.A., Bruns G.A., et al. Human neutrophil cytochrome b light chain (p22-phox). Gene structure, chromosomal location, and mutations in cytochrome-negative autosomal recessive chronic granulomatous disease. J Clin Invest 1990; 86: 1729-1737.

16. Pittock S.J., Meldrum D., Hardiman O., et al. The Oxfordshire Community Stroke Project classification: correlation with imaging, associated complications, and prediction of outcome in acute ischemic stroke. J Stroke Cerebrovasc Dis 2003; 12: 1-7.

17. Niemiec P., Zak I., Wita K. The $242 \mathrm{~T}$ variant of the CYBA gene polymorphism increases the risk of coronary artery disease associated with cigarette smoking and hypercholesterolemia. Coron Artery Dis 2007; 18: 339-346.
18. Wyche K.E., Wang S.S., Griendling K.K., et al. C242T CYBA polymorphism of the NADPH oxidase is associated with reduced respiratory burst in human neutrophils. Hypertension 2004; 43: 1246-1251.

19. Shimo-Nakanishi Y., Hasebe T., Suzuki A., et al. Functional effects of $\mathrm{NAD}(\mathrm{P}) \mathrm{H}$ oxidase $\mathrm{p} 22$ (phox) $\mathrm{C} 242 \mathrm{~T}$ mutation in human leukocytes and association with thrombotic cerebral infarction. Atherosclerosis 2004; 175: 109-115.

20. Macías-Reyes A., Rodríguez-Esparragón F., Caballero-Hidalgo A., et al. Insight into the role of CYBA A640G and C242T gene variants and coronary heart disease risk. A case-control study. Free Radic Res 2008; 42: 82-92.

21. Nakano T., Matsunaga S., Nagata A., et al. NAD(P)H oxidase p22phox Gene C242T polymorphism and lipoprotein oxidation. Clin Chim Acta 2003; 335:101-107.

22. Ito D., Murata M., Watanabe K., et al. C242T polymorphism of NADPH oxidase p22 PHOX gene and ischemic cerebrovascular disease in the Japanese population. Stroke 2000; 31: 936-939.

23. Kuroda J., Kitazono T., Ago T., et al. NAD(P)H oxidase p22phox C242T polymorphism and ischemic stroke in Japan: the Fukuoka Stroke Registry and the Hisayama study. Eur J Neurol 2007; 14: 1091-1097.

24. Genius J., Grau A.J., Lichy C. The C242T polymorphism of the $\mathrm{NAD}(\mathrm{P}) \mathrm{H}$ oxidase p22phox subunit is associated with an enhanced risk for cerebrovascular disease at a young age. Cerebrovasc Dis 2008; 26: 430-433. 